\title{
Effects of eutrophication and Typha domingensis Pers on methanogenesis in tropical constructed wetland
}

\author{
Efeitos da eutrofização e da Macrófita Aquática Typha domingensis Pers \\ sobre a metanogênese em alagados construídos tropicais
}

Joanna Maria da Cunha de Oliveira Santos Neves ${ }^{1}$, Glauca Torres Aragon ${ }^{2}$ and Emmanoel Vieira da Silva Filho ${ }^{1}$

${ }^{1}$ Departamento de Geoquímica, Instituto de Química, Universidade Federal Fluminense - UFF,

Outeiro de São João Batista, CEP 24020-141, Niterói, RJ, Brazil

e-mail: joanna_cunha_santos@yahoo.com.br, glauca.aragon@gmail.com

${ }^{2}$ Laboratório de Ciências Ambientais, Universidade Estadual do Norte Fluminense - UENF,

Av. Alberto Lamego, 2000, CEP 28013-602, Campos dos Goytacazes, RJ, Brazil e-mail: geoemma@vm.uff.br

\begin{abstract}
Aim: Constructed wetlands (CWs) have shown to be an efficient way for removing nutrients from wastewaters. However, a negative effect is the emission of greenhouse gases (GHGs). Methane $\left(\mathrm{CH}_{4}\right)$ is a GHG released from the organic matter degradation under anaerobic conditions by methanogenic bacteria. In CWs, the excessive nutrient inputs may stimulate both primary production and methanogenesis and then affect the overall cost-benefit balance of this system. Here, we assessed the role of cattail stands (Typha domingensis Pers) on $\mathrm{CH}_{4}$ concentrations in eutrophic and mesotrophic constructed wetlands. Methods: CWs were filled with water and sediment colonized by the aquatic macrophyte Typh a domingensis Pers from two tropical freshwater lakes, one mesotrophic and another eutrophic. Results: Our results showed consistently higher $\mathrm{CH}_{4}$ concentrations in waters and sediment in the eutrophic CWs than in the mesotrophic CWs (two times), indicating a positive influence of eutrophication on methanogenesis. Conclusion: In conclusion, $\mathrm{CH}_{4}$ emissions from tropical CWs demand to be considered or even mitigated in any use of this system.
\end{abstract}

Keywords: methane, constructed wetlands, Typha domingensis Pers.

Resumo: Objetivo: Os alagados contruídos (CWs) tem sido evidenciados como uma maneira eficiente de remover nutrientes presentes em efluentes. No entanto, um efeito negativo desse processo é a emissão de gases de efeito estufa (GHGs). Metano $\left(\mathrm{CH}_{4}\right)$ é um gás estufa liberado a partir da degradação da matéria orgânica sob condiçóes anaeróbicas mediada por bactérias metanogênicas. Em alagados construídos, as entradas excedentes de nutrientes podem estimular a produção primária e a metanogênese então pode afetar todo o balanço entre custo-benefício do sistema. Métodos: Nesse trabalho, foi investigado o papel dos bancos de macrófitas (Typha domingensis Pers) sobre as concentrações de $\mathrm{CH}_{4}$ em alagados construídos eutróficos e mesotróficos. Os alagados construídos foram elaborados com água e sedimento colonizado por macrófitas aquáticas da espécie Typha domingensis Pers provenientes de duas lagoas tropicais, uma mesotrófica e a outra eutrófica. Resultados: Os resultados indicaram concentraçôes de $\mathrm{CH}_{4}$ significativamente superiores (duas vezes) na coluna d'água e no sedimento nos alagados construídos eutróficos do que nos alagados construídos mesotróficos, fato que indica a influência positiva da eutrofização sobre a metanogênese. Conclusão: Como conclusão, as emissōes de metano em alagados construídos tropicais devem ser consideradas e mitigadas, caso esses sistemas sejam utilizados.

Palavras-chave: metano, alagados construídos, Typha domingensis Pers. 


\section{Introduction}

The use of constructed wetlands (CWs) as an alternative to conventional wastewater treatment has increased in recent decades in order to reduce the excessive nutrient loading from human activities (Vymazal et al., 1998; MaltaisLandry et al., 2009). These systems can act as buffers between the main sources of pollution and natural watercourses by reducing the inputs of nitrogen $(\mathrm{N})$ and phosphorous $(\mathrm{P})$, nutrients that result in eutrophication of freshwater and saline systems (Schindler, 2006). However, CWs show high emissions of greenhouse gases, including methane $\left(\mathrm{CH}_{4}\right)$. This gas is produced during the last step of organic degradation under anaerobic conditions (Jones, 1991; Boone, 1991; Fonseca et al., 2004; Conrad et al., 2010). Methanogenesis is influenced by temperature (Kang and Freeman, 2002), redox potential, $\mathrm{pH}$, organic matter contents (VanHulzen et al., 1999; Bodegom and Stams, 1999), salinity, absence of oxygen (Keltjens and Vogels, 1993; Oren, 1994; Munson et al., 1997; Thauer, 1998) and other electrons acceptors (Lovley et al., 1982).

High emissions of $\mathrm{CH}_{4}$ to the atmosphere have been observed especially from warm tropical inland waters (Bastviken et al., 2010). Tropical wetlands are broadly distributed in Brazil. These ecosystems are often degraded by the human activities. Nutrient-enriched inputs from sewage, agricultural fertilizers or residuals from the sugarcane processing, for biodiesel production, have been commonly related to eutrophication in inland waters and wetlands at low latitudes. Our hypothesis is that the high nutrient levels in eutrophic constructed wetlands with Typha domingensis Pers. favor the the methanogenesis.

\section{Material and Methods}

\subsection{Experimental design}

We used twelve $40 \mathrm{~L}-\mathrm{CWs}$ (length $41.0 \mathrm{~cm}$, height $32.0 \mathrm{~cm}$, depth $41.0 \mathrm{~cm}$ ) with controlled temperature in a greenhouse. Details of the CWs design are illustrated in the Figure 1. The CWs were filled with water and sediment and replanted with Typha domingensis Pers. from two tropical lakes in Brazil (one eutrophic - Lake Vigário - and another mesotrophic - Lake Cima). Lake Vigário receives the inputs of sugarcane residuals and domestic waste, while Lake Cima only sugarcane residuals. Both lake are costal coastal, shallow (maximum depth $<5.0 \mathrm{~m}$ ) and relatively close to one another.
The hydrochemical characterization of the water column and sediments from these eutrophic and mesotrophic lake are presented in Table 1.

Lake Vigário (area of $0,3 \mathrm{~km}^{2}$ ) is a urban ecosystem located between Parque Guarus and Parque Prazeres neighborhoods in Campos dos Goytacazes City, Rio de Janeiro state, Brazil $\left(21^{\circ} 45^{\prime} 15^{\prime \prime} \mathrm{S}\right.$ and $\left.41^{\circ} 19^{\prime} 28^{\prime \prime} \mathrm{W}\right)$. This lake displays an intense development of a marginal population that settled in around from the 60's,

\section{Constructed wetlands (CWs) with macrophyte}

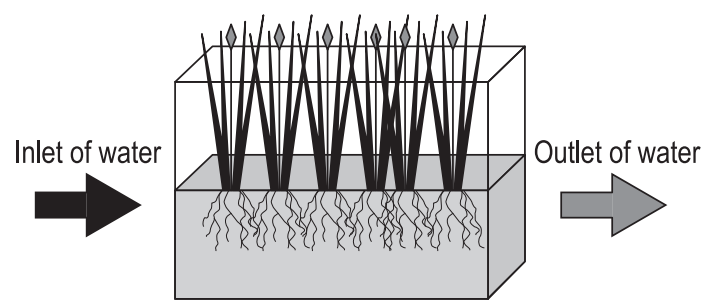

Constructed wetlands (CWs) without macrophyte

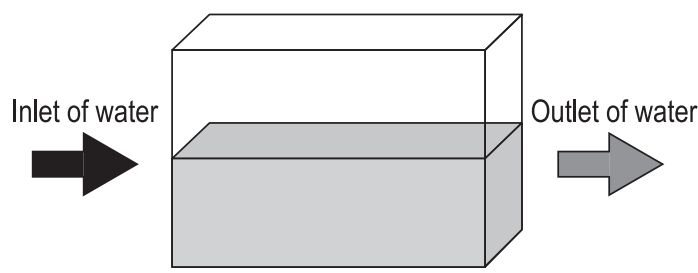

Figure 1. Experimental design of constructed wetlands (CWs), showing planted and unplanted plots with Typha domingensis Pers.

Table 1. Nitrogen, Phosphorus and Organic Carbon in waters and the sediment of Lake Vigário and Lake Cima (References: ${ }^{1}$ Lannes, 2004 and ${ }^{2}$ Santos, 2003).

\begin{tabular}{|c|c|c|}
\hline Parameters & $\begin{array}{c}\text { Vigario } \\
\text { Lake }^{1}\end{array}$ & $\begin{array}{l}\text { Cima } \\
\text { Lake }^{2}\end{array}$ \\
\hline \multicolumn{3}{|c|}{ Concentrations in water column } \\
\hline $\mathrm{N}-\mathrm{NH}_{4}^{+}\left(\mu \mathrm{g} \cdot \mathrm{L}^{-1}\right)$ & 160.0 & 30.6 \\
\hline $\mathrm{N}-\mathrm{NO}_{2}^{-}\left(\mu \mathrm{g} \cdot \mathrm{L}^{-1}\right)$ & 20.0 & 4.6 \\
\hline $\mathrm{N}^{-\mathrm{NO}_{3}}{ }^{-}\left(\mu \mathrm{g} \cdot \mathrm{L}^{-1}\right)$ & 110.0 & 8.7 \\
\hline $\mathrm{P}_{-} \mathrm{PO}_{4}^{-3}\left(\mu \mathrm{g} \cdot \mathrm{L}^{-1}\right)$ & 40.0 & 65.8 \\
\hline $\mathrm{DOC}\left(\mu \mathrm{g} \cdot \mathrm{L}^{-1}\right)$ & 16800.0 & 54.0 \\
\hline \multicolumn{3}{|c|}{ Concentrations in sediments } \\
\hline$C\left(m g \cdot L^{-1}\right)$ & 93.7 & - \\
\hline $\mathrm{N}\left(\mathrm{mg} \cdot \mathrm{L}^{-1}\right)$ & 4.0 & - \\
\hline$P\left(m g \cdot L^{-1}\right)$ & 0.2 & - \\
\hline
\end{tabular}

\begin{tabular}{lrr}
\hline \multicolumn{3}{c}{ Physico-chemical Parameters of water column } \\
\hline $\mathrm{pH}$ & 8.2 & 6.7 \\
$\mathrm{Eh}$ & 119.0 & 233.0 \\
Electrical conductivity $\left(\mu \mathrm{S} . \mathrm{cm}^{-1}\right)$ & 827.0 & 39.2 \\
Total Alkalinity $\left(\mathrm{mEq}\right.$. $\left.\mathrm{L}^{-1}\right)$ & 2.3 & 0.1 \\
Dissolved Oxygen $\left(\mathrm{mg}_{\mathrm{L}} \mathrm{L}^{-1}\right)$ & 8.1 & 8.7 \\
\hline
\end{tabular}


being a receptor of wastewater. The lake is densely colonized by emergent and floating aquatic macrophytes, respectively Typha domingensis Pers and Eicchornia crassipes (Lannes, 2004), but the marginal area colonized by this vegetation has been substantially reduced by silting up from human activities. Lake Vigário shows $\mathrm{pH}$ around 7.5 and electrical conductivity around $0.7 \mathrm{mS} . \mathrm{cm}^{-1}$ (Lannes, 2004). On the other hand, Lake Cima has a lower human disturbance. This lake is located in the northern region of Rio de Janeiro state, in Campos dos Goytacazes ( $21^{\circ} 45^{\prime} 23^{\prime \prime} \mathrm{S}, 41^{\circ} 19^{\prime} 49^{\prime}$ W), showing freshwaters with a conductivity around $50 \mu \mathrm{S} . \mathrm{cm}^{-1}$ (Luz, 2003).

The experimental design was conducted using two hydraulic systems containing six 40 L-boxes of asbestos and one 200 L-box (general source of water). In each one of $40 \mathrm{~L}$-boxes, a drip system on the surface to keep constant the water level with the continuous water inflow(water depth was maintained in $15 \mathrm{~cm}$, accordingly to Figure 1). Three CWs filled with sediment and waters from each mesotrophic and eutrophic lake were planted with the aquatic macrophyte Typha domingensis Pers collected in the respective lakes (five young individuals), while other three were kept unplanted, in order to assess the effects of macrophytes on the methane concentrations in waters and sediments.. First measurements in our experimental CWs were conducted after 30 days for stabilization.

$\mathrm{CH}_{4}$ concentrations in waters and the bottom sediment were analyzed $5 \mathrm{~mL}$ of surface waters which were collected in all CWs water surface using. Water samples $(5 \mathrm{~mL})$ were taken using plastic syringes with needle and stored in $10 \mathrm{~mL}-$ glass vials closed with massive rubber stoppers. In addition, a small amount of $\mathrm{NaCl}$ was added in each vial to expurgate methane from waters to the headspace (Casper, 1992). These vials were kept under refrigeration before headspace analysis in a Gas Cromatographer (GC-14B Shimadzu), using a chromatographic packed column Porapak-Q at $60{ }^{\circ} \mathrm{C}$; column injector at $120^{\circ} \mathrm{C}$, FID detector at $200{ }^{\circ} \mathrm{C}$, and nitrogen was adopted as gas carrier. Then, $4 \mathrm{~mL}$ of $\mathrm{NaOH} 4 \%(\mathrm{v} / \mathrm{v})$ was added using a syringe with needle to expurge $\mathrm{CH}_{4}$ from the pore water to the headspace (Casper, 1992). After shaking, $0.2 \mathrm{~mL}$ of gas from headspace was also extracted using plastic syringes with needle, and then injected in the GC described above). Abiotic variables measured during the experiment in waters were temperature, electrical conductivity, $\mathrm{pH}$, total alkalinity and dissolved oxygen using a calibrated multiparametric probe (Hanna Instruments). Additionally, we determined the macrophyte growth measuring height, leaves, and a general characterization of sediment from all experimental CWs (granulometry - wet sieving and organic matter contents - dry weight) (Kimble et al., 2001). Data were not normally distributed even after transformations (Kolmogorov-Smirnov, $\mathrm{p}<0.05$ ). Non parametric tests were then used to compare differences (Kruskal-Wallis followed by the Dunn`s post test, significant $\mathrm{p}<0.05$ for both).

\section{Results}

Table 2 indicates the variation of physicochemical parameters from Eutrophic CWs (Lake Vigário) planted and unplanted plots; and Table 3 indicates the variation of physico-chemical parameters from mesotrophic CWs (Lake Cima) planted and unplanted plots during experimental time.

$\mathrm{pH}$, temperature, electrical conductivity, redox potential, alkalinity and dissolved oxygen concentration in waters were not significantly different comparing CWs within each eutrophic and mesotrophic lake (Kruskal-Wallis, p > 0.05). Granulometric fractions of the sediment and the
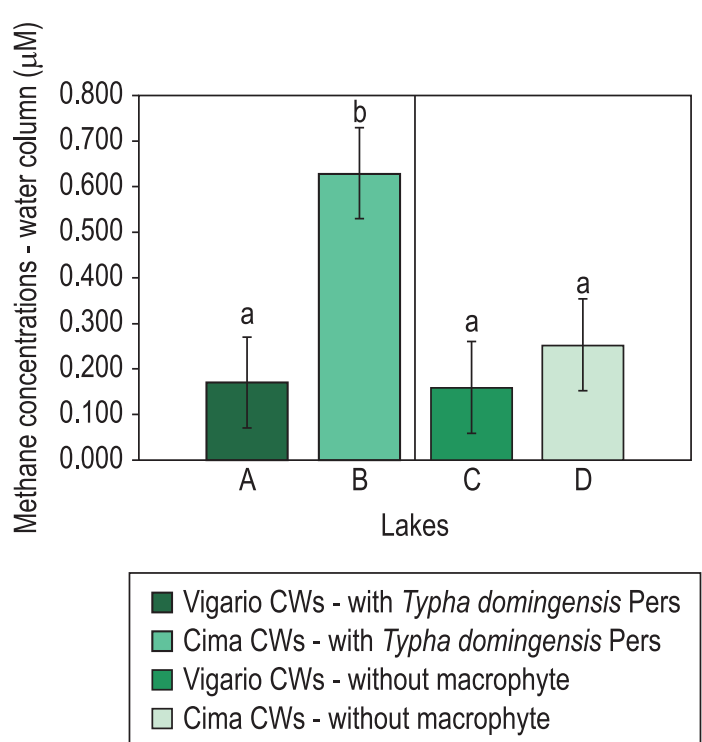

Figure 2. $\mathrm{CH}_{4}$ concentrations in waters of eutrophic (Lake Vigário) and mesotrophic (Lake Cima) CW`s with and without macrophyte. a) Lake Vigário CWs with macrophyte Typha domingensis Pers; b) Lake Vigário CWs without macrophyte; c) Lake Cima CWs with Typha domingensis Pers; and d) Lake Cima unplanted plots. Distinct letters $(a, b)$ show significant differences among treatments, for each lake separately (Kruskal-wallis test (95\% s level of significance) and Dunn's test (95\% of level of significance). 
Table 2. Variation of physico-chemical parameters from Eutrophic CWs (Lake Vigário) planted and unplanted plots during experimental time.

\begin{tabular}{|c|c|c|c|c|c|c|}
\hline \multirow[t]{2}{*}{ Samples } & \multicolumn{3}{|c|}{ Boxes with macrophyte } & \multicolumn{3}{|c|}{ Boxes without macrophyte } \\
\hline & CW1 & CW2 & CW3 & CW4 & CW5 & CW6 \\
\hline \multicolumn{7}{|c|}{ Water temperature $\left({ }^{\circ} \mathrm{C}\right)$} \\
\hline First week & 25,0 & 26,7 & 25,8 & 27,1 & 27,5 & 27,3 \\
\hline Second week & 27,0 & 28,2 & 27,3 & 28,2 & 28,0 & 28,4 \\
\hline Third week & 29,0 & 29,7 & 29,6 & 29,7 & 28,9 & 28,6 \\
\hline Fourth week & 27,0 & 29,2 & 29,5 & 30,2 & 29,4 & 29,2 \\
\hline Average & 27,0 & 28,5 & 28,1 & 28,8 & 28,5 & 28,4 \\
\hline SD & 1,6 & 1,3 & 1,8 & 1,4 & 0,9 & 0,8 \\
\hline VC & 6,0 & 4,6 & 6,6 & 4,9 & 3,0 & 2,8 \\
\hline \multicolumn{7}{|c|}{ Electrical conductivity $\left(\mu \mathrm{S} \mathrm{cm}^{-1}\right)$} \\
\hline First week & 1173 & 1105 & 1056 & 954 & 875 & 745 \\
\hline Second week & 1293 & 1052 & 1123 & 978 & 910 & 729 \\
\hline Third week & 1120 & 1030 & 1079 & 1007 & 956 & 810 \\
\hline Fourth week & 1250 & 1076 & 1125 & 1032 & 1004 & 725 \\
\hline Average & 1209,0 & 1065,8 & 1095,8 & 992,8 & 936,3 & 752,3 \\
\hline SD & 77,4 & 32,2 & 34,0 & 34,0 & 56,0 & 39,5 \\
\hline VC & 6,4 & 3,0 & 3,1 & 3,4 & 6,0 & 5,2 \\
\hline \multicolumn{7}{|c|}{$\mathrm{pH}$} \\
\hline First week & 6,65 & 6,40 & 6,80 & 7,12 & 7,11 & 7,66 \\
\hline Second week & 6,57 & 6,39 & 6,75 & 6,96 & 6,94 & 7,25 \\
\hline Third week & 6,49 & 6,27 & 6,69 & 6,79 & 6,70 & 6,78 \\
\hline Fourth week & 6,38 & 6,23 & 6,56 & 6,82 & 6,69 & 6,53 \\
\hline Average & 6,52 & 6,32 & 6,70 & 6,92 & 6,86 & 7,06 \\
\hline SD & 0,12 & 0,09 & 0,10 & 0,15 & 0,20 & 0,50 \\
\hline VC & 1,77 & 1,35 & 1,55 & 2,18 & 2,96 & 7,11 \\
\hline \multicolumn{7}{|c|}{ Eh } \\
\hline First week & 196 & 87 & 110 & 170 & 90 & 110 \\
\hline Second week & 73 & 125 & 112 & 108 & -12 & 135 \\
\hline Third week & 220 & 202 & 180 & 195 & 20 & 205 \\
\hline Fourth week & 236 & 223 & 235 & 203 & 36 & 176 \\
\hline Average & 181,3 & 159,3 & 159,3 & 169,0 & 33,5 & 156,5 \\
\hline SD & 74,0 & 64,0 & 60,1 & 43,0 & 42,6 & 42,3 \\
\hline VC & 40,8 & 40,2 & 37,7 & 25,5 & 127,2 & 27,0 \\
\hline \multicolumn{7}{|c|}{ Total alkalinity $\left(\mathrm{mEq} . \mathrm{L}^{-1}\right)$} \\
\hline First week & 3,2 & 2,8 & 2,6 & 2,0 & 2,0 & 2,2 \\
\hline Second week & 3,7 & 3,1 & 2,9 & 2,2 & 2,4 & 2,4 \\
\hline Third week & 3,1 & 3,2 & 3,1 & 2,4 & 2,5 & 2,8 \\
\hline Fourth week & 4,1 & 3,3 & 2,7 & 2,9 & 3,0 & 3,1 \\
\hline Average & 3,5 & 3,1 & 2,8 & 2,4 & 2,5 & 2,6 \\
\hline SD & 0,5 & 0,2 & 0,2 & 0,4 & 0,4 & 0,4 \\
\hline VC & 13,1 & 6,3 & 7,8 & 15,1 & 16,5 & 15,7 \\
\hline \multicolumn{7}{|c|}{ Dissolved oxygen $\left(\mathrm{mg} \mathrm{L}^{-1}\right)$} \\
\hline First week & 2,4 & 2,59 & 2,35 & 3,21 & 3,02 & 2,9 \\
\hline Second week & 2,93 & 2,62 & 2,26 & 3,02 & 2,53 & 2,36 \\
\hline Third week & 2,32 & 2,15 & 2,14 & 2,5 & 2,48 & 2,08 \\
\hline Fourth week & 1,97 & 1,56 & 1,89 & 1,07 & 1,22 & 1,12 \\
\hline Average & 2,4 & 2,2 & 2,2 & 2,5 & 2,3 & 2,1 \\
\hline SD & 0,4 & 0,5 & 0,2 & 1,0 & 0,8 & 0,7 \\
\hline VC & 16,5 & 22,2 & 9,2 & 39,5 & 33,2 & 35,3 \\
\hline
\end{tabular}


Table 3. Variation of physico-chemical parameters from mesotrophic CWs (Lake Cima) planted and unplanted plots.

\begin{tabular}{|c|c|c|c|c|c|c|}
\hline \multirow[t]{2}{*}{ Samples } & \multicolumn{3}{|c|}{ Boxes with macrophyte } & \multicolumn{3}{|c|}{ Boxes without macrophyte } \\
\hline & CW1 & CW2 & CW3 & CW4 & CW5 & CW6 \\
\hline \multicolumn{7}{|c|}{ Water temperature $\left({ }^{\circ} \mathrm{C}\right)$} \\
\hline First week & 28,3 & 27,5 & 26,9 & 28,5 & 27,9 & 27,2 \\
\hline Second week & 27,5 & 28,2 & 27,3 & 28,9 & 28,2 & 28,6 \\
\hline Third week & 29,0 & 28,7 & 27,9 & 29,2 & 28,6 & 29,2 \\
\hline Fourth week & 28,3 & 29,3 & 29,6 & 29,8 & 28,9 & 28,7 \\
\hline Average & 28,3 & 28,4 & 27,9 & 29,1 & 28,4 & 28,4 \\
\hline SD & 0,6 & 0,8 & 1,2 & 0,5 & 0,4 & 0,9 \\
\hline $\mathrm{VC}$ & 2,2 & 2,7 & 4,3 & 1,9 & 1,5 & 3,0 \\
\hline \multicolumn{7}{|c|}{ Electrical Conductivity $\left(\mu \mathrm{S} \mathrm{cm}^{-1}\right)$} \\
\hline First week & 42,0 & 45,7 & 42,3 & 52,7 & 56,3 & 42,9 \\
\hline Second week & 47,0 & 49,0 & 46,0 & 50,3 & 59,7 & 53,6 \\
\hline Third week & 56,0 & 54,0 & 54,3 & 45,0 & 41,6 & 57,2 \\
\hline Fourth week & 59,0 & 48,2 & 57,8 & 42,3 & 42,5 & 47,4 \\
\hline Average & 51,0 & 49,2 & 50,1 & 47,6 & 50,0 & 50,3 \\
\hline SD & 7,9 & 3,5 & 7,2 & 4,8 & 9,3 & 6,4 \\
\hline VC & 15,4 & 7,1 & 14,3 & 10,0 & 18,6 & 12,7 \\
\hline \multicolumn{7}{|c|}{$\mathrm{pH}$} \\
\hline First week & 6,7 & 6,9 & 6,8 & 6,7 & 6,5 & 6,7 \\
\hline Second week & 6,5 & 6,7 & 6,7 & 6,5 & 6,3 & 6,6 \\
\hline Third week & 6,2 & 6,6 & 6,7 & 6,5 & 6,3 & 6,6 \\
\hline Fourth week & 6,4 & 6,0 & 6,5 & 6,3 & 6,0 & 6,3 \\
\hline Average & 6,5 & 6,6 & 6,7 & 6,5 & 6,3 & 6,6 \\
\hline SD & 0,2 & 0,4 & 0,1 & 0,2 & 0,2 & 0,2 \\
\hline VC & 3,2 & 5,9 & 1,9 & 2,5 & 3,3 & 2,6 \\
\hline \multicolumn{7}{|c|}{ Eh } \\
\hline First week & 229 & 234 & 312 & 253 & 232 & 220 \\
\hline Second week & 275 & 221 & 298 & 243 & 227 & 216 \\
\hline Third week & 178 & 252 & 276 & 240 & 220 & 208 \\
\hline Fourth week & 154 & 198 & 254 & 224 & 214 & 210 \\
\hline Average & 209,0 & 226,3 & 285,0 & 240,0 & 223,3 & 213,5 \\
\hline SD & 54,0 & 22,7 & 25,4 & 12,0 & 7,9 & 5,5 \\
\hline VC & 25,8 & 10,0 & 8,9 & 5,0 & 3,5 & 2,6 \\
\hline \multicolumn{7}{|c|}{ Total alkalinity (mEq. $\left.\mathrm{L}^{-1}\right)$} \\
\hline First week & 0,63 & 0,64 & 0,60 & 0,66 & 0,63 & 0,62 \\
\hline Second week & 0,55 & 0,60 & 0,56 & 0,64 & 0,57 & 0,56 \\
\hline Third week & 0,42 & 0,57 & 0,43 & 0,56 & 0,54 & 0,54 \\
\hline Fourth week & 0,52 & 0,42 & 0,47 & 0,52 & 0,58 & 0,57 \\
\hline Average & 0,5 & 0,6 & 0,5 & 0,6 & 0,6 & 0,6 \\
\hline SD & 0,1 & 0,1 & 0,1 & 0,1 & 0,0 & 0,0 \\
\hline $\mathrm{VC}$ & 16,4 & 17,2 & 15,2 & 11,1 & 6,5 & 5,9 \\
\hline \multicolumn{7}{|c|}{ Dissolved oxygen $\left(\mathrm{mg} . \mathrm{L}^{-1}\right)$} \\
\hline First week & 7,6 & 7,4 & 7,4 & 7,0 & 6,9 & 6,5 \\
\hline Second week & 7,0 & 7,2 & 7,2 & 6,7 & 6,5 & 6,2 \\
\hline Third week & 6,5 & 7,2 & 7 & 6,5 & 6,2 & 6,0 \\
\hline Fourth week & 6,2 & 6,8 & 6,4 & 6,3 & 5,9 & 6,0 \\
\hline Average & 6,8 & 7,2 & 7,0 & 6,6 & 6,4 & 6,2 \\
\hline SD & 0,6 & 0,3 & 0,4 & 0,3 & 0,4 & 0,2 \\
\hline VC & 9,0 & 3,5 & 6,2 & 4,5 & 6,7 & 3,8 \\
\hline
\end{tabular}


organic matter contents indicated that the silt-clay fraction was predominant for both lakes. Higher organic matter contents were observed in the eutrophic than in the mesotrophic lake sediments, respectively 14 and $8 \% . \mathrm{CH}_{4}$ concentrations in waters of the eutrophic CWs (Figure 2 and Table 4) ranged from 0.13 to $1.40 \mu \mathrm{mol} . \mathrm{L}^{-1}$, showing higher values than in mesotrophic CWs $(0.12$ $0.55 \mu \mathrm{mol} . \mathrm{L}^{-1}$, Figure 2). Comparing planted and unplanted eutrophic $\mathrm{CWs}, \mathrm{CH}_{4}$ concentrations were higher in planted than in unplanted plots (Kruskal-Wallis, $\mathrm{p}<0.05$ and Dunn, $\mathrm{p}<0.05$ ), but no significant differences were observed between mesotrophic CWs (Kruskal-Wallis, $\mathrm{p}<0.05$ ). Indeed, we did not find any significant relationship between presence of vegetation and methane concentrations in mesotrophic CWs, (linear regression, $\left.\mathrm{R}^{2}=0.61 ; \mathrm{p}<0.05\right)$. Planted plots also showed higher methane concentrations in waters than unplanted plots, considering both eutrophic and mesotrophic CWs (Kruskal-Wallis, $\mathrm{p}<0.05$ and Dunn, $\mathrm{p}<0.05)$.

Typha domingensis was not related to significant differences for $\mathrm{CH}_{4}$ concentrations in eutrophic and mesotrophic CWs (Kruskal-Wallis, $\mathrm{p}<0.05$ and Dunn, $\mathrm{p}<0.05)$. Higher methane concentrations in waters were found in eutrophic CWs, ranging from 63.4 to $69.7 \mu \mathrm{mol} . \mathrm{L}^{-1}$, than in mesotrophic CWs (Kruskal-Wallis test: $\mathrm{p}<0.05$ and Dunn's test $\mathrm{p}<0.05$ ), ranging from 29.3 to $34.1 \mu \mathrm{mol} . \mathrm{L}^{-1}$. In the sediment, methane concentrations in the eutrophic CWs were higher than in mesotrophic ones, ranging from 50.2 to $79.6 \mathrm{mmol} . \mathrm{L}^{-1}$ and from 26.6 to $36.2 \mu \mathrm{mol} . \mathrm{L}^{-1}$ respectively (Figure 3 ). Planted and unplanted eutrophic CWs showed methane concentrations in the sediment significantly higher than those mesotrophic (Kruskal-Wallis test: $\mathrm{p}<0.05$ and Dunn's test $\mathrm{p}<0.05)$.

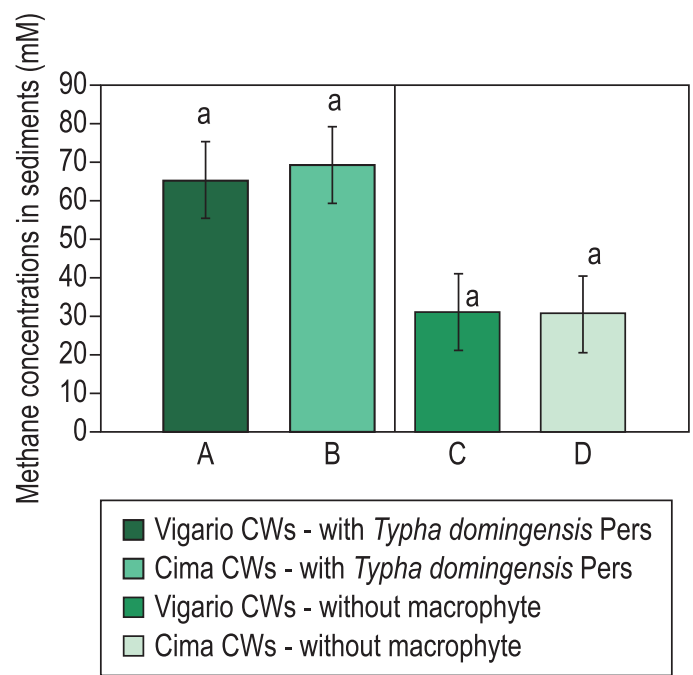

Figure 3. $\mathrm{CH}_{4}$ concentrations in the sediment of eutrophic (Lake Vigário) and mesotrophic (Lake Cima) CWs with and without macrophyte. a) Lake Vigário CWs with macrophyte Typha domingensis Pers; b) Lake Vigário CWs without macrophyte; c) Lake Cima CWs with Typha domingensis Pers; and d) Lake Cima unplanted plots. For sediments analysis, no were found significant differences among treatments, for each lake separately (Kruskal-Wallis test (95\% level of significance) and Dunn's test (95\% of level of significance).

Table 4. Results obtained with Dunn's test for evaluate the significant differences of treatments (with Typha domingensis Pers and without macrophyte) for Lake Vigário CWs (eutrophic) and Lake Cima CWs (mesotrophic).

\begin{tabular}{cccc}
\hline & MSD & Critical value & Interpretation \\
\hline Treatments Vigario CWs & 6.09 & 2.93 & Significant difference \\
Tratments Cima CWs & 2.33 & 2.93 & Not significant \\
\hline
\end{tabular}

Table 5. Methane concentration in waters for others aquatic ecosystems.

\begin{tabular}{lcc}
\hline \multicolumn{1}{c}{ Location } & $\mathrm{CH}_{4}\left(\mu \mathrm{mol} . \mathrm{L}^{-1}\right)$ & References \\
\hline Freshwater marsh - China (vegetated) & $8.0-232.0$ & Ding et al. (2004) \\
Cabiunas lagoon - Rio de Janeiro, Brazil & $12.3-16.4$ & Fonseca et al. (2004) \\
Diogo lake - São Paulo, Brazil (macrophyte stand) & $0.84-2.60$ & Ballester and Santos (2001) \\
Diogo lake - São Paulo, Brazil (limnetic region) & $0.73-1.35$ & Ballester and Santos (2001) \\
Agacha river - Georgia, USA & $0.33-1.65$ & Pulliam (1993) \\
Grasil lake - Fuchskahld, Germany & $3.7-14.7$ & Chan et al. (2002 \\
Denmark coast & 0.0004 (maximum) & Hansen et al. (2001) \\
Mediterranean sea & $0.0015-0.0045$ & Karisiddaiah (2000) \\
Open water (water surface) & $0.0018-0.0031$ & Heyer (1990) \\
Cima CWs - Rio de Janeiro, Brazil & 0.12 v 0.55 & This research \\
Vigario CWs - Rio de Janeiro, Brazil & $0.13-1.40$ & This research \\
\hline
\end{tabular}




\section{Discussion}

Our results consistently indicate a positive influence from eutrophication and the presence of aquatic macrophyte Typha domingensis Pers on methanogenesis. Additionally, high alkalinity of eutrophic CWs is likely caused by the sewage inputs into this lake, supporting anaerobic processes of organic matter cycling (Brix et al., 1996; Singh, 2001; Chang and Yang, 2003; Wang and Han, 2005).

For unplanted eutrophic CWs, $\mathrm{CH}_{4}$ concentrations in waters and sediments increased over the experiment, confirming lower $\mathrm{CH}_{4}$ production related to absence of aquatic macrophyte (Chan et al., 2002). In contrast, higher $\mathrm{CH}_{4}$ concentrations found in eutrophic CWs were likely caused by the sewage inputs into Lake Vigário, increasing the availability of organic substrates to methanogenesis (Neue et al., 1995, Singh et al., 2000; Liikanen and Martikainen, 2003).

Lake Vigário is a freshwater lake, nonetheless in this lake is important detach the role of sulphatereduction competing with methanogenesis by organic substrates in Lake Vigário (Lannes, 2004); high methane concentrations in waters and sediments of CWs also suggested potentially elevated rates of methanogenesis in this eutrophic lake. This confirms that besides sulphate-reduction, the methanogenesis might be also an important organic degradation processes under highly eutrophic conditions that are typically related to substantial sewage inputs.

Planted plots also showed higher $\mathrm{CH}_{4}$ concentrations in waters than those unplanted, confirming the role of the aquatic vegetation to increase methanogenesis like in artificial rice fields (Schütz et al., 1989) or natural tropical lakes (Bastviken et al., 2010). The $\mathrm{CH}_{4}$ concentrations observed in experimental CWs are within the range for other tropical lakes in Brazil (Table 5), with the exception was a brackish tropical coastal lagoons (e.g. Lagoon Cabiúnas), which showed lower $\mathrm{CH}_{4}$ concentrations probably by the higher salinity limiting $\mathrm{CH}_{4}$ production (Fonseca et al., 2004).

In conclusion, we clearly support our hypothesis as the eutrophic conditions led to elevate $\mathrm{CH}_{4}$ in eutrophic CWs. Our data suggested that sewage discharges enriched in organic substrates and nutrients besides other subsequent hydrochemical conditions, such as redox potential and $\mathrm{pH}$, could positively affect $\mathrm{CH}_{4}$ production in aquatic environments. Although the measures of methane flux through macrophytes have not been made in this study, macrophyte Typha domingensis Pers may be acting as methane source to the atmosphere, as is widely discussed in literature. This shows the importance of eutrophication and organic matter contents in eutrophic CWs, reducing dissolved oxygen and stimulating methanogenesis. The use of constructed wetlands is usually applied for wastewater treatment and nutrient removal, but the GHG's emissions to the atmosphere demand to be considered and subsequently mitigated. Our data confirms the contribution of constructed wetlands for GHG production; nonetheless further investigations mainly in tropical ecosystems are required.

\section{Acknowledgements}

This study was supported by Fundação de Amparo a Pesquisa do Estado do Rio de Janeiro - FAPERJ.

\section{References}

BALLESTER, MVR. and SANTOS, JE. 2001. Biogenic gases $\left(\mathrm{CH}_{4}, \mathrm{CO}_{2}\right.$ and $\left.\mathrm{O}_{2}\right)$ distribution in a riverine wetlands system. In FARIA, BM., FARJALLA, VF. and ESTEVES, FA., eds. Aquatic Microbial Ecology in Brazil. Rio de Janeiro: UFRJ. Series Oecologia Brasiliensis. vol. 9, p. 21-30.

BASTVIKEN, D., SANTORO, AL., MAROTTA, H., PINHO, LQ., CALHEIROS, DF., CRILL, P. and ENRICH-PRAST, A. 2010. Methane emission from Pantanal, South America, during low water season: toward more comprehensive sampling. Environmental Science and Technology, vol. 44, p. 5450-5455. http:// dx.doi.org/10.1021/es 1005048

BODEGOM, PMV. and STAMS, AJM. 1999. Effects of alternative electron acceptors and temperature on methanogenesis in rice paddy soils. Chemosphere, vol. 39, no. 2, p. 167-182. http://dx.doi.org/10.1016/ S0045-6535(99)00101-0

BOONE, DR. 1991. Ecology of methanogenesis. In ROGERS, JE. and WHITMAN, WE., eds. Microbial production and consumption of greenhouse gases: methane, nitrogen oxides and halomethanes. Washington: American Society of Microbiology.

BRIX, H., BRIAN, K. and SORREL, HH. 1996. Gas fluxes achieved by in situ convective flow in Phragmites australis. Aquatic Botany, vol. 54, no. 2-3, p. 151-163. http://dx.doi.org/10.1016/03043770(96)01042-X

CASPER, P. 1992. Methane production in lakes of different trophic state. Archiv für HydrobiologieBeiheft Ergebnisse der Limnologie, vol. 37, p. 149-154.

CHAN, OC., WOLF, M., HEPPERLE, D. and CASPER, P. 2002. Methanogenic archael community 
in the sediment of an artificially portioned acidic bog lake. FEMS Microbiology Ecology, vol. 42, p. 119-129.

CHANG, TC. and YANG, SS. 2003. Methane emissions from wetlands in Taiwan. Atmospheric Environment, vol. 37, no. 32, p. 4551-4558.

CONRAD, R., KLOSE, M., CLAUS, P. and ENRICHPRAST, A. 2010. Methanogenic pathway 13C isotope fractioning, and archaeal community composition in the sediment of two clear-water lakes of Amazonia. Limnology and Oceanography, vol. 55, no. 2, p. 689-702. http://dx.doi.org/10.4319/ lo.2009.55.2.0689

DING, W., CAI, Z. and TSURUTA, H. 2004. Methane concentration and emissions affected by methane transport capacity of plants in freshwater marsh. Water, air and soil pollution, vol. 158, p. 99-111. http://dx.doi.org/10.1023/ B:WATE.0000044836.71634.3d

FONSECA, ALS., MINELLO, M., MARINHO, CC. and ESTEVES, FA. 2004. Methane Concentration in Water Column and in Pore Water of a Coastal Lagoon (Cabiúnas Lagoon, Macaé, RJ, Brazil). Brazilian Archives of Biology and Technology, vol. 47, no. 2, p. 301-308. http://dx.doi.org/10.1590/S151689132004000200018

HANSEN, LK., JAKOBSEN, R. and POSTMA, D. 2001. Methanogenics in a shallow sandy aquifer, Romo, Denmark. Geochimica et Cosmochimica Acta, vol. 65, no. 17, p. 2925-2935. http://dx.doi. org/10.1016/S0016-7037(01)00653-6

HEYER, J. 1990. Der Kreislauf des Methans. Berlin: Akademie-Verlag.

JONES, WJ. 1991. Diversity and physiology of methanogens. In ROGERS, JE. and WHITMAN, WB., eds. Microbial Production and Consumption of Greenhouse gases: Methane, Nitrogen oxides and Halomethanes. Washington: American Society for Microbiology.

KANG, H. and FREEMAN, C. 2002. The influence of hydrochemistry on methane emissions from two contrasting northern wetlands. Water, air and soil pollution, vol. 141, no. 1-4, p. 263-272. http://dx.doi. org/10.1023/A:1021324326859

KIMBLE, JM., LAL, R. and FOLLET, RF. 2001. Methods for assessing soil C pools. In LAL, R., KIMBLE, JM., FOLLET, RF. and STEWART, BA., eds. Assessment methods for soil carbon: Advances in soil science. BocaRaton: CRC Press.

KELTJENS, JT. and VOGELS, GD. 1993. Conversion of methanol and methylamines to methane and carbon dioxide. In FERRY, JG., eds. Methanogenesis. New York: Chapman and Hall.

LANNES, LS. 2004. Avaliação de pequenos alagados artificiais na modificação da qualidade de água utilizando a macrófita aquática Typha domingensis Pers. Campos dos Goytacazes: Universiade Estadual do Norte Fluminense. [Tese de Doutorado em Biociência e Biotecnologia].

LIIKANEN, A. and MARTIKAINEN, PJ. 2003. Effect of ammonium and oxygen on methane and nitrous oxide fluxes across sediment-water interface in a eutrophic lake. Chemosphere, vol. 52, no. 8, p. 1287-1293. http://dx.doi.org/10.1016/S00456535(03)00224-8

LOVLEY, DR., DWEYER, DF. and KLUG, MJ. 1982. Kinetic analysis of competition between sulfate reducers and methanogens for hydrogen in sediments. Applied Environmental Microbiology, vol. 43, no. 6, p. 1373-1379.

LUZ, CFP. 2003. Os registros palinológicos como sensores das dinâmicas da vegetaçãono Holoceno da Regiāo Norte do Estado do Rio de Janeiro (Brasil). Rio de Janeiro : Instituto de Geociências, Universidade Federal do Rio de Janeiro. [Tese de Doutorado em Geologia].

MALTAIS-LANDRY, G., MARANGER, R. and BRISSON, J. 2009. Effect of artificial and macrophyte species on nitrogen cycling and gas flu in constructed wetlands. Ecologycal Engineering, vol. 35, p. 221-229.

MUNSON, MA., NEDWELL, DB. and EMBLEY, TM. 1997. Phylogenetic diversity of Archaea in sediment samples from a coastal salt marsh. Applied Environmental Microbiology, vol. 63, no. 3, p. 47294733.

NEUE, HU., WASSMANN, R., LANTIN, RS., ALBERTO, MA., ADUNA, JB. and JAVELLANA, AM. 1995. Factors affecting methane emission from rice fields. Atmospheric Environment, vol. 30, no. 1011, p. 1751-1754. http://dx.doi.org/10.1016/13522310(95)00375-4

OREN, A. 1994. The ecology of the extremely halophilic Archaea. FEMS Microbiology Ecology, vol. 13, no. 4, p. 415-440.

PULLIAM, WM. 1993. Carbon dioxide and methane exports from a southeastern floodplain swamp. Ecological Monographs, vol. 63, no. 1, p. 29-53. http:// dx.doi.org/10.2307/2937122

SANTOS, JMCO. 2003. Compartimentação biogeoquimica da bacia de drenagem do Rio Imbé. Campos dos Goytacazes: Universidade Estadual do Norte Fluminense. [Monografia de Graduação em Biologia].

SCHINDLER, DW. 2006. Recent advances in the understanding and management of eutrophication. Limnology and Oceanography, vol. 51, no. 1, part 2, p. 356-36.

SCHÜTZ, H., HOLZAPFEL-PSCHORN, A., CONRAD, R., RENNENBERG, H. and SEILER, W. 1989. A three year continuous record on influence of daytime, season and fertilize treatment on methane emission: rates from an Italian rice paddy field. Journal of Geophysical Research, D Atmospheres, vol. 94, no. 16. 
SINGH, SN. 2001. Exploring correlation between redox potential and other edaphic factors in field and laboratory conditions in relation to methane efflux. Environmental International, vol. 27, no. 4, p. 265-274. http://dx.doi.org/10.1016/S01604120(01)00055-1

SINGH, SN., KULSHRESHTHA, K. and AGNIHOTRI, S. 2000. Seasonal dynamics of methane emission from wetlands. Chemosphere: Global Change Science, vol. 2, no. 1, p. 39-46. http://dx.doi.org/10.1016/S1465-9972(99)00046-X

THAUER, R. 1998. Biochemistry of methanogenesis: a tribute to Marjory Stephenson. Microbiology, vol. 144, no. 9, p. 2377-2406. PMid:9782487. http:// dx.doi.org/10.1099/00221287-144-9-2377
VAN-HULZEN, JB., SEGERS, R., VAN BODEGOM and LEFFELAAR, PM. 1999. Temperature effects on soil methane production: an explanation for observed variability. Soil Biology Biochemistry, vol. 31, no. 14, p. 1919-1929. http://dx.doi.org/10.1016/S00380717(99)00109-1

VYMAZAL, J., BRIX, H., COOPER, PF., GREEN, MB. and HABERL, R. 1998. Constructed wetlands for wastewater treatment in Europe. Leiden: Blackhyus Publishers.

WANG, ZP. and HAN, X.G. 2005. Diurnal variation in methane emissions in relation to plants and environmental variables in the Inner Mongolia marshes. Atmospheric Environment, vol. 39, no. 34, p. 6295-6305. http://dx.doi.org/10.1016/j. atmosenv.2005.07.010

Received: 21 October 2010 Accepted: 23 November 2011 